\title{
Unprecedented Coordination-Induced Bright Red Emission from Group 12 Metal-Bound Triarylazoimidazoles
}

\author{
Artyom A. Astafiev ${ }^{1,2}$, Olga V. Repina ${ }^{1,3}$, Boris S. Tupertsev ${ }^{1,3}$, Alexey A. Nazarov ${ }^{2} \mathbb{D}$, Maria R. Gonchar ${ }^{2}$, \\ Anna V. Vologzhanina ${ }^{4}\left(\mathbb{D}\right.$, Valentine G. Nenajdenko ${ }^{2} \mathbb{D}$, Andreii S. Kritchenkov ${ }^{3}$, Victor N. Khrustalev ${ }^{3,5}{ }^{(0)}$, \\ Victor N. Nadtochenko ${ }^{1,2}$ and Alexander G. Tskhovrebov ${ }^{1,3, *}$
}

check for updates

Citation: Astafiev, A.A.; Repina, O.V.; Tupertsev, B.S.; Nazarov, A.A.; Gonchar, M.R.; Vologzhanina, A.V.; Nenajdenko, V.G.; Kritchenkov, A.S.; Khrustalev, V.N.; Nadtochenko, V.N.; et al. Unprecedented CoordinationInduced Bright Red Emission from Group 12 Metal-Bound Triarylazoimidazoles. Molecules 2021, 26, 1739. https://doi.org/ $10.3390 /$ molecules26061739

Academic Editors: Lidia Armelao and Jorge H. Monteiro

Received: 14 February 2021

Accepted: 17 March 2021

Published: 20 March 2021

Publisher's Note: MDPI stays neutral with regard to jurisdictional claims in published maps and institutional affiliations.

Copyright: (C) 2021 by the authors Licensee MDPI, Basel, Switzerland This article is an open access article distributed under the terms and conditions of the Creative Commons Attribution (CC BY) license (https:// creativecommons.org/licenses/by/ $4.0 /)$
1 N.N. Semenov Federal Research Center for Chemical Physics, Russian Academy of Sciences, Kosygina 4, 119991 Moscow, Russia; astafiev.artyom@gmail.com (A.A.A.); repina.ov@phystech.edu (O.V.R.); btoupersev@gmail.com (B.S.T.); nadtochenko@gmail.com (V.N.N.)

2 Lomonosov Moscow State University, Chemistry Department, Leninskie Gory 1/3, 119991 Moscow, Russia; alexey.nazarov@me.com (A.A.N.); mari.kainas@yandex.ru (M.R.G.); nenajdenko@gmail.com (V.G.N.)

3 Peoples' Friendship University of Russia, Miklukho-Maklaya Street 6, 117198 Moscow, Russia; platinist@mail.ru (A.S.K.); vnkhrustalev@gmail.com (V.N.K.)

4 A.N. Nesmeyanov Institute of Organoelement Compounds, Russian Academy of Sciences, Vavilova Street 28 119334 Moscow, Russia; vologzhanina@mail.ru

5 N.D. Zelinsky Institute of Organic Chemistry, Russian Academy of Sciences, 47 Leninsky Prospect, 119334 Moscow, Russia

* Correspondence: alexander.tskhovrebov@chph.ras.ru

Abstract: Arylazoimidazoles are important dyes which were intensively studied in the past. In contrast, triarylazoimidazoles (derivatives which carry aryl substituents at the imidazole core) received almost no attention in the scientific literature. Here, we report a new family of simple and easily accessible triarylazoimidazole-group 12 metal complexes, which feature highly efficient photo-luminescence emission ( $\Phi$ up to 0.44 ). Novel compounds exhibit bright red emission in solution, which could be excited with a visible light.

Keywords: azo dyes; nitrogen heterocycles; fluorescence; group 12 metal complexes

\section{Introduction}

Emissive metal complexes are the key components or rapidly developing critical technologies, including organic light-emitting diodes (OLED) [1,2] photovoltaics [3,4] sensing [5,6] bioimaging [7] photodynamic therapy [8], and photocatalysis [9,10]. The progress in these areas significantly depends on the improvement of physical characteristics and their fine tuning via chemical manipulations with metal complexes' structures [11]. Their fundamental importance and applicability stimulate active search for the new families of emissive metal complexes.

In this context, azoimidazoles are attractive chelating ligands with easily tunable electronic and photophysical properties via facile structural modifications [12-17]. Recently, we described a novel method for the synthesis of this important class of dyes, which employs nitrous oxide as a donor of azo group [17-19].

From the photophysics research perspective, azoimidazoles, being representatives of classical molecular switches, were comprehensively studied due to their important photochromic properties [20,21]. They are believed to be promising for applications in photopharmacology and bioinorganic chemistry since imidazole moiety is an essential group in biology, often serving as a supporting ligand in metal-containing systems [20,21]. In general, photoswitchable late transition metal complexes hold promise for the development of novel methods which would feature advantageous control of drug-action specificity [22]. Therefore, exploration of coordination chemistry of cytotoxic metals, which contain potentially photoswitchable heterocyclic ligands seemed promising. 
Following our interest in azo dyes and photochromic materials $[17,18,23]$, we turned our attention to triarylazoimidazoles and their metal complexes. Surprisingly, triarylazoimidazoles received almost no attention in the literature [24-27]. Therefore, exploration of their coordination chemistry, photophysics or photochemistry and cytotoxicity seemed as an attractive niche.

Unexpectedly, coordination of triarylazoimidazoles to group 12 metals resulted in the formation of complexes with bright red emission (quantum yields up to $44 \%$ ), which could be excited with a visible light.

\section{Results and Discussion}

\subsection{Synthesis and Structural Characterization}

Triarylazoimidazoles 3 and 4 were prepared via azo coupling between $p$-anisyldiazonium tetrafluoroborate and corresponding diarylimidazoles (Scheme 1) and isolated in high yields as red solids.<smiles></smiles>

$\mathrm{R}=\mathrm{H}(\mathbf{1}), \mathrm{OMe}(2)$<smiles>COc1ccc([N+]#N)cc1</smiles><smiles>C1CC1</smiles><smiles>[R]c1ccc(-c2nc(N/N=C/c3ccc(OC)cc3)[nH]c2-c2ccc([R])cc2)cc1</smiles>

$\mathrm{R}=\mathrm{H}(\mathbf{3}), \mathrm{OMe}(\mathbf{4})$

Scheme 1. Synthesis of triarylazoimidazoles 3 and 4 .

When a solution of $\mathrm{ZnCl}_{2}$ in methanol was added to a solution of 3 in methanol the color immediately changed to dark-red and dichroic dark-green/brown microcrystalline precipitate of $\mathbf{5}$ gradually formed. Isolation and analysis of the precipitate suggested the formation of an adduct in $46 \%$ yield (Scheme 2). A similar procedure was used to form $\mathrm{Cd}$ and $\mathrm{Hg}$ complexes of 3 and $\mathrm{Zn}, \mathrm{Cd}$, and $\mathrm{Hg}$ complexes of 4 . The corresponding compounds 6-10 were isolated with yields between 43 and 71\% (Scheme 2).
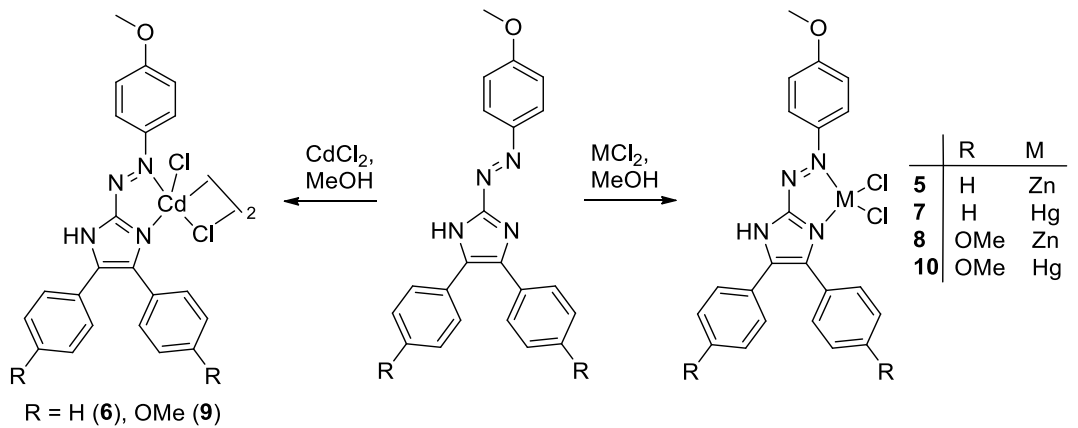

Scheme 2. Synthesis of triarylazoimidazole complexes 5-10.

Complexes 5, 7-10 precipitated from the reaction mixtures as well-shaped crystals, suitable for analysis by single crystal X-ray crystallography. The structural investigations confirmed the formation of $\mathrm{Zn}^{\mathrm{II}}$, $\mathrm{Cd}^{\mathrm{II}}$ and $\mathrm{Hg}^{\mathrm{II}}$ complexes with chelating triarylazoimidazoles (Figure 1). The ligands in 5, 7-10 adopt a trans configuration around the $\mathrm{N}=\mathrm{N}$ bond with the azoimidazole moieties being nearly planar: dihedral $\mathrm{N}-\mathrm{C}-\mathrm{N}-\mathrm{N}$ lie between $0.05(8)^{\circ}$ and $2.9(6)^{\circ}$, while $\mathrm{C}_{\mathrm{Ar}}-\mathrm{C}_{\mathrm{Ar}}-\mathrm{N}-\mathrm{N}$ angles do not exceed $3.6(8)^{\circ}$, what indicates on a significant electronic conjugation in rigid chelating triarylazoimidazoles. 


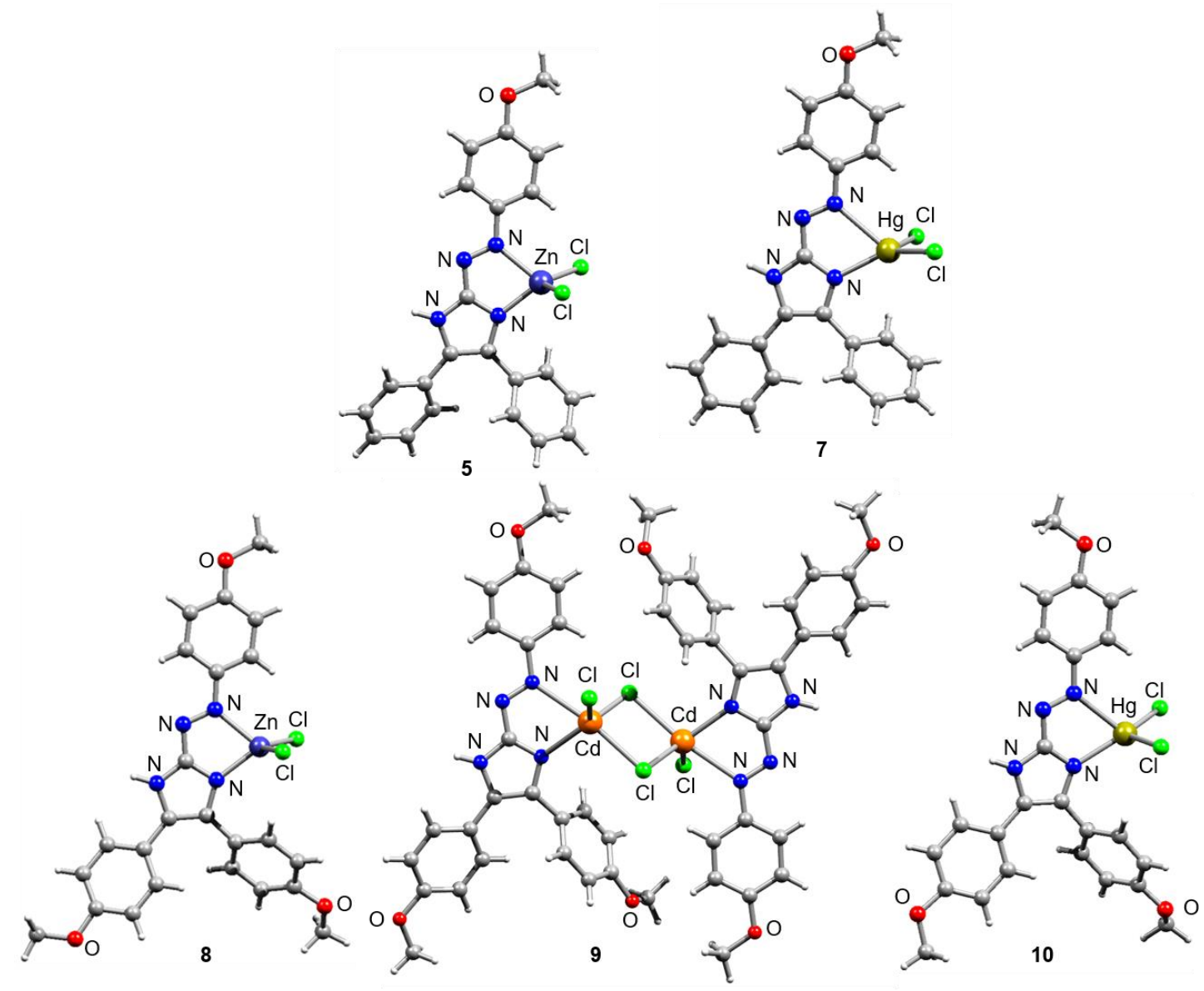

Figure 1. Ball-and-stick representation of the structure of 5, 7-10 in the crystal. Solvent molecules are omitted. Grey and light grey spheres represent carbon and hydrogen atoms, respectively.

Metal centers in 5, 7, 8, 10 adopt distorted tetrahedral geometry (Table 1) with terminal chloride atoms, while in $\mathbf{9}$ one of two symmetrically independent chlorides act as bridging ligands so that ligands around $\mathrm{Cd}^{\mathrm{II}}$ center adopt distorted trigonal bipyramidal geometry. The $\mathrm{M}-\mathrm{Cl}$ and $\mathrm{M}-\mathrm{N}$ bond distances increase and the $\mathrm{N}-\mathrm{M}-\mathrm{N}$ and $\mathrm{Cl}-\mathrm{M}-\mathrm{Cl}$ angles decrease with the increase in the ionic radii of $\mathrm{Zn}^{\mathrm{II}}, \mathrm{Hg}^{\mathrm{II}}$ and $\mathrm{Cd}^{\mathrm{II}}$.

Table 1. Selected geometrical parameters $\left(\AA^{\circ},{ }^{\circ}\right)$ for $\mathbf{5 , 7 - 1 0 . ~}$

\begin{tabular}{|c|c|c|c|c|c|}
\hline & $5 \cdot \mathrm{CH}_{3} \mathrm{OH}$ & $8 \cdot \mathrm{CH}_{3} \mathrm{OH}$ & $7 \cdot \mathrm{CH}_{3} \mathrm{OH}$ & $10 \cdot \mathrm{CH}_{3} \mathrm{OH}$ & $9 \cdot 2 \mathrm{CH}_{3} \mathrm{OH}$ \\
\hline M & $\mathrm{Zn}^{\mathrm{II}}$ & $\mathrm{Zn}^{\mathrm{II}}$ & $\mathrm{Hg}^{\mathrm{II}}$ & $\mathrm{Hg}^{\mathrm{II}}$ & $\mathrm{Cd}^{\mathrm{II}}$ \\
\hline $\mathrm{M}-\mathrm{Cl}$ & $2.1929(8)-2.2300(8)$ & $2.1852(4)-2.2401(4)$ & $2.337(1)-2.493(1)$ & $2.366(2)-2.477(2)$ & $2.441(2)-2.629(1)$ \\
\hline $\mathrm{M}-\mathrm{N} 1_{\mathrm{Im}}$ & $2.023(2)$ & $2.023(1)$ & $2.189(3)$ & $2.224(5)$ & $2.252(3)$ \\
\hline $\mathrm{M}-\mathrm{N} 4_{\mathrm{azo}}$ & $2.151(2)$ & $2.147(1)$ & $2.536(3)$ & $2.501(6)$ & $2.551(3)$ \\
\hline $\mathrm{N} 1_{\mathrm{Im}}-\mathrm{M}-\mathrm{N} 4_{\mathrm{azo}}$ & $78.2(1)$ & $77.83(5)$ & $68.0(1)$ & $69.9(2)$ & $68.5(1)$ \\
\hline $\mathrm{Cl}-\mathrm{M}-\mathrm{Cl}$ & $117.43(3)$ & $119.09(2)$ & $111.51(4)$ & $114.22(7)$ & $89.05(5)-121.45(5)$ \\
\hline Cl1-M-N & $113.0(1)-122.0(1)$ & $116.24(3)-118.09(4)$ & $99.91(9)-105.8(1)$ & $113.2(2)-136.2(2)$ & 97.8(1)-118.6(1) \\
\hline $\mathrm{Cl} 2-\mathrm{M}-\mathrm{N}$ & $108.82(6)-110.36(7)$ & $106.57(4)-111.49(4)$ & $122.6(1)-137.5(1)$ & $104.9(2)-106.1(2)$ & 85.43(8)-116.7(1) \\
\hline N1-C & $1.371(3)$ & $1.371(2)$ & $1.365(5)$ & $1.368(8)$ & $1.366(5)$ \\
\hline $\mathrm{N} 1=\mathrm{C}$ & $1.339(3)$ & $1.335(1)$ & $1.325(5)$ & $1.335(9)$ & $1.330(5)$ \\
\hline $\mathrm{C}-\mathrm{N}(\mathrm{H})$ & $1.341(3)$ & $1.346(2)$ & $1.349(5)$ & $1.344(8)$ & $1.338(5)$ \\
\hline$(\mathrm{Ar}) \mathrm{C}-\mathrm{N} 1_{\mathrm{azo}}$ & $1.388(3)$ & $1.381(2)$ & $1.391(5)$ & $1.394(8)$ & $1.387(4)$ \\
\hline $\mathrm{N}(\mathrm{H})-\mathrm{C}(\mathrm{Ar})$ & $1.372(3)$ & $1.378(2)$ & $1.375(5)$ & $1.381(8)$ & $1.372(4)$ \\
\hline$(\mathrm{Ar}) \mathrm{C}=\mathrm{C}(\mathrm{Ar})$ & $1.396(4)$ & $1.405(2)$ & $1.392(5)$ & $1.398(9)$ & $1.386(5)$ \\
\hline $\mathrm{N}=\mathrm{N}$ & $1.286(3)$ & $1.287(2)$ & $1.270(5)$ & $1.276(7)$ & $1.273(4)$ \\
\hline $\mathrm{Ar}-\mathrm{C}$ & $1.473(4)-1.478(4)$ & $1.461(2)-1.476(2)$ & $1.464(4)-1.482(5)$ & $1.459(8)-1.475(9)$ & $1.465(5)-1.513(5)$ \\
\hline Ar- $\mathrm{N}_{\text {azo }}$ & $1.404(3)$ & $1.398(2)$ & $1.400(5)$ & $1.398(8)$ & $1.406(4)$ \\
\hline
\end{tabular}


Structures of 5, 7-10 contained one solvated methanol molecule per one metal atom, which participated in hydrogen bonding with $\mathrm{N}-\mathrm{H}$ protons and chlorides (Figure S1). Interestingly, the $\mathrm{M}-\mathrm{Cl}$ bond involved in hydrogen bonding was longer than the other $\mathrm{M}-\mathrm{Cl}$ bond what is typical for relatively weak coordination bonds with significant ionic contribution. For 5 and 9 the hydrogen bonding resulted in the formation of infinite chains, while in 7, 8 and 10-hydrogen bonded tetramers were formed (Figure S1) [28-31].

\subsection{Absorption and Emission Profiles}

The optical properties of free ligands ( 3 and 4 ) were quite different from their group 12 metal complexes (5-10). Electronic absorption spectra for 3 and its complexes 5-7 are shown in Figure 2 while for $\mathbf{4}$ and 8-10 in Figure S2.

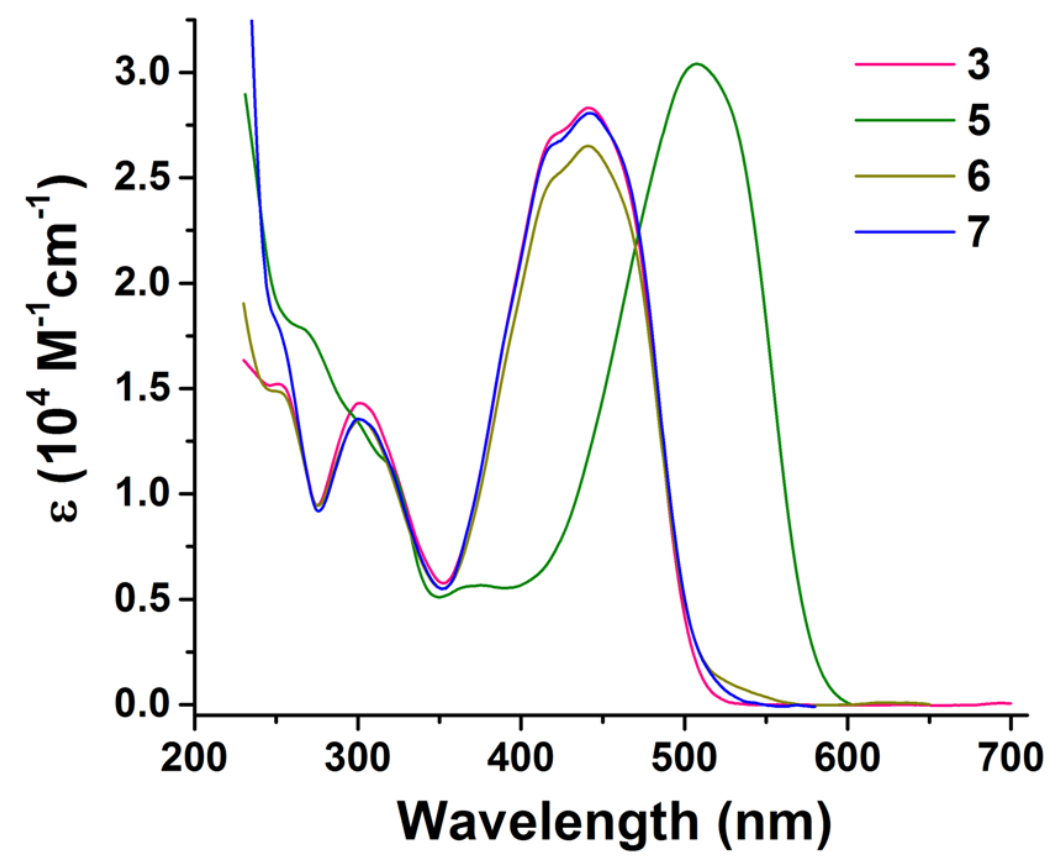

Figure 2. Absorption spectra of 3 and its group 12 metal complexes 5-7 in $\mathrm{CH}_{2} \mathrm{Cl}_{2}$. ( $\varepsilon$-extinction coefficient).

Triarylazoimidazole 3 exhibited a broad absorption band with a fine structure and maximum at $441 \mathrm{~nm}$, which was assigned to intraligand $\pi-\pi^{*}$ transitions in the azoimidazole moiety with a considerable charge transfer from azoaryl group (donor) to imidazole fragment (acceptor) [20,21]. This charge transfer band was redshifted compared to what was observed for intensively studied arylazoimidazoles which do not contain aryl substituents at the imidazole ring [20,21]. Tri(p-anisyl)azoimidazole 4 exhibited a similar blue absorption band (Figure S2), but its maximum expectedly experienced a bathochromic shift compared to that of 3 .

Coordination of 3 and 4 to group 12 metals resulted in changes in their absorption spectra (Figure 2). This effect was relatively weak for the cadmium (6) and mercury (7) derivatives, for which the main absorption band decreased slightly and a small tail appeared in the $>500 \mathrm{~nm}$ spectral region. Binding of 4 to $\mathrm{Hg}^{\mathrm{II}}$ and $\mathrm{Cd}^{\mathrm{II}}$ resulted in similar changes in the absorption spectra.

Interestingly, absorption spectra of $\mathrm{Zn}{ }^{\mathrm{II}}$ complexes $\mathbf{5}$ and $\mathbf{8}$ differed dramatically from that of free ligands 3 and 4 . Absorption spectra of 5 and 8 featured a new strong band in the green spectral region which was redshifted by $67 \mathrm{~nm}$ (5) and $77 \mathrm{~nm}(8)$, compared to the absorption maxima of free ligands (Figure 2 and Figure S2). Second derivative analysis of the new peak of complex 5 (Figure S3) revealed it was heterogeneous and consisted of two overlapping peaks with maxima at ca. 498 and $536 \mathrm{~nm}$, which probably corresponded 
to $\mathrm{S}_{0} \rightarrow \mathrm{S}_{2}$ and $\mathrm{S}_{0} \rightarrow \mathrm{S}_{1}$ transitions, respectively. The strongest absorption band of $\mathbf{8}$ exhibited the second derivative minimum at circa $560 \mathrm{~nm}$.

We hypothesize that coordination caused a red shift of main charge transfer absorption band of the ligand and emergence of a new absorption band in the region $>500 \mathrm{~nm}$. That can be seen from the second derivative analysis which revealed that the main absorption peak of 5 consists of two closely situated components at 498 and $536 \mathrm{~nm}$ (see the SI). The first is obviously the ligand-based charge transfer transition from donating $p$-methoxyphenyl to the accepting azoimidazole group. It was red-shifted compared to the $\mathrm{CT}$ absorption peak of the free ligand at $441 \mathrm{~nm}$ due to coordination to the $\mathrm{Zn}$ metal center. The second component emerged as a result of coordination. Its maximum generally coincides with photoluminescence excitation maximum at $540 \mathrm{~nm}$ meaning that this transition populates the electronic level from which emission occurs. In complexes 6 and 7 the coordinationinduced shift of $\mathrm{CT}$ absorption maximum was negligible and the coordination-induced component appeared as a weak absorption tail beyond $500 \mathrm{~nm}$. The stronger effect of $\mathrm{Zn}$ coordination on absorption spectra is obviously related to the smaller size of $\mathrm{Zn}^{2+}$, resulting in a stronger coordination bond. The same effects (red shift of CT absorption maximum and emergence of yellow components in absorption spectra) were observed for the complexes 8-10.

Remarkably, when a solution of 5 was subjected to white light, it showed an orangered fluorescence seen to the naked eye while free ligand 3 exhibits no emission (even when irradiated with the UV light). Photoluminescence (PL) spectrum of 5 in $\mathrm{CH}_{2} \mathrm{Cl}_{2}$ exhibited a peak with emission maximum at $598 \mathrm{~nm}$ with a high quantum yield (39\%), while photoluminescence excitation (PLE) spectrum showed a peak at $543 \mathrm{~nm}$ (Figure 3). A moderate Stokes shift $(0.2 \mathrm{eV})$ observed between PLE and PL spectra is indicative structural differences between the ground and excited states in $\mathbf{5}$. Normalized PL spectra of $\mathbf{5}$ did not dependent of the excitation wavelength, what was in accord with Vavilov-Kasha rule and was expected for such kind of a system.

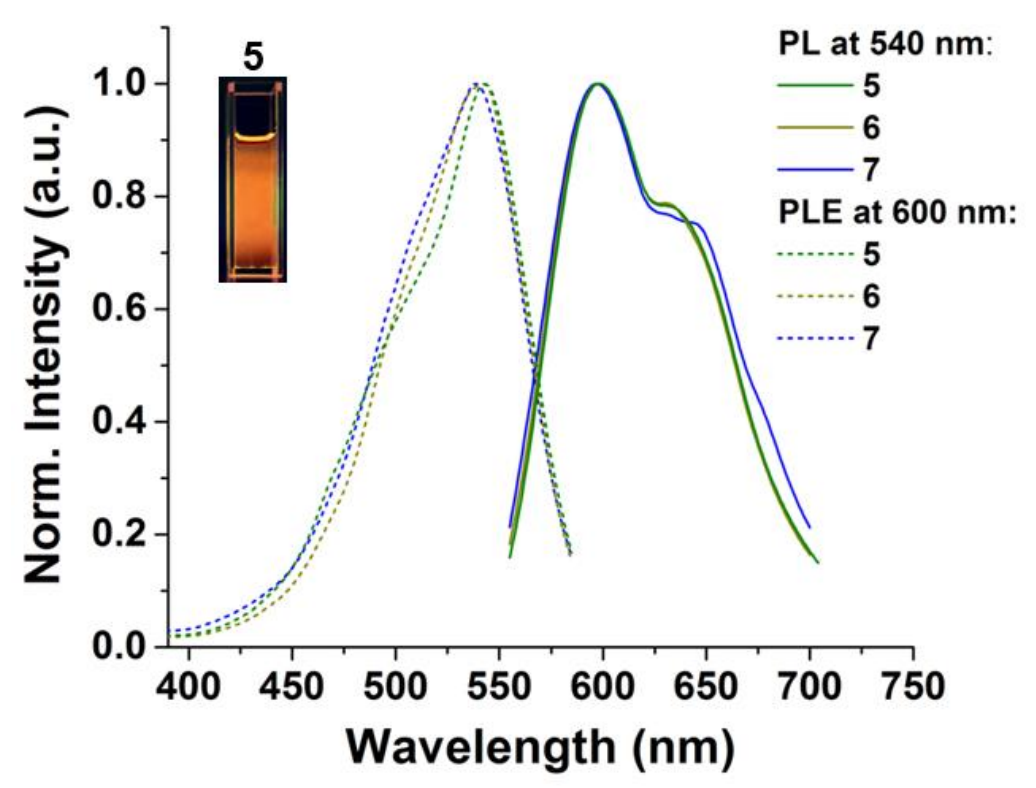

Figure 3. Normalized photoluminescence (PL) and photoluminescence excitation (PLE) spectra of 5-7 in $\mathrm{CH}_{2} \mathrm{Cl}_{2}$. (a.u.- - arbitrary unit)

A plausible explanation of the origin of the emission in the molecule of 5 could be a $\pi-\pi^{*}$ transition in a rigid coordinated triphenylazoimidazole, while in unbound azo-dye excitation could result in trans-to-cis isomerization, which serves as a relaxation channel for the excited states to decay non-radiatively. Photochemical isomerization around the $\mathrm{N}=\mathrm{N}$ is intensively studied phenomenon, which was also reported for azoimidazoles [20,21]. 
Thus, coordination of triphenylazoimidazole at $\mathrm{Zn}$ (II) metal center blocks the nonradiative pathway and opens the radiative channel.

Interestingly, PL and PLE spectra of analogous $\mathrm{Cd}(\mathrm{II})$ and $\mathrm{Hg}(\mathrm{II})$ derivatives $\mathbf{6}$ and 7 qualitatively looked very similar to the Zn(II) complex 5 (Figure S1), which indicated that the origin of the emission was ligand-based, but fluorescence quantum yields of 6 and 7 (less than 9\%) turned to be much smaller than that of 5. PL spectra of 5-7 exhibited a shoulder at ca. $635 \mathrm{~nm}$ close to the main peak at ca. $600 \mathrm{~nm}$, which suggested a presence of two radiative transitions of slightly different energy. PLE spectra of 5-7 also exhibited a shoulder at ca. $496 \mathrm{~nm}$.

Fluorescence decay kinetics of 5 in $\mathrm{CH}_{2} \mathrm{Cl}_{2}$ showed single-exponential behavior with a lifetime of 2.59 ns (Figure 4). In contrast, emission decay kinetics of 6 and 7 exhibited faster and multiexponential decay, dominated by a fast decay time (Figure 4). The fast decay component for 6 was about $0.24 \mathrm{~ns}$, while for 7 it was at the level of time-correlated single photon counting (TCSPC) resolution and estimated at about 20 ps from a decay kinetic deconvolution. The decrease in the fluorescence lifetime found for $\mathrm{Zn}, \mathrm{Cd}$, and $\mathrm{Hg}$ triad 5-7 was in agreement with a trend observed for the fluorescence quantum yield.
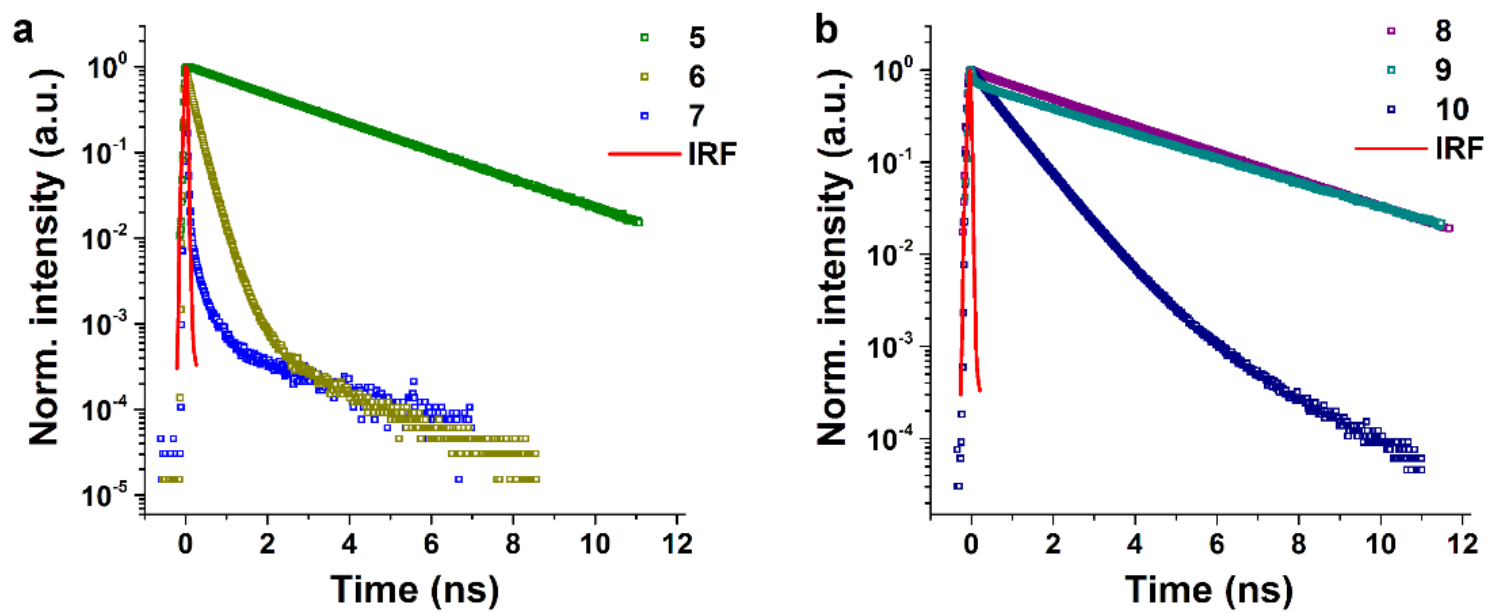

Figure 4. Fluorescence decay kinetics of 5-7 (a) and 8-10 (b) in $\mathrm{CH}_{2} \mathrm{Cl}_{2}$. Decay kinetics were monitored at $600 \mathrm{~nm}$ for 5-7 and at $660 \mathrm{~nm}$ for $\mathbf{8 - 1 0}$. Instrumental response function (IRF) is plotted as a solid red line.

PL and PLE spectra of 8-10 looked similar to that of 5-7 but featured larger Stokes shift (0.26-0.32 eV vs. $0.20-0.23 \mathrm{eV}$ ) (Figure 5). PL spectra of 8-10 showed a single broad band with a maximum at $660 \mathrm{~nm}$ and no fine structure. Fluorescence quantum yields for 8-10 (44, 39, 10\%, respectively) turned out to be even higher than that of 5-7 (Table S2). Fluorescence decay kinetics of $\mathbf{8}$ was nearly monoexponential with a lifetime of ca. 2.9 ns (Figure 4, Table S3). Decay kinetic of 9 had a similar decay time but also a short decay component. That agrees with a smaller quantum yield of 9 in $\mathrm{CH}_{2} \mathrm{Cl}_{2}$ solution. Finally, photoluminescence decay of $\mathrm{Hg}$ complex 10 was dominated by a fast component with a decay time of $0.74 \mathrm{~ns}$, the ratio of effective decay times of 8 and $\mathbf{1 0}$ (4:1) roughly corresponded to the ratio of quantum yields (4.5:1).

Photophysical studies for 5-10 in solvents of varying polarity were not successful since, in coordinating solvents, solvent molecules coordinated to azoimidazole-bound metal centers, leading to spectral changes and luminescence quantum yield which goes beyond the scope of this paper. In non-polar the complexes are virtually insoluble. PL and PLE spectra of 5 in different are given in Figure S7.

Moreover, binuclear complex 9 has generally similar photoluminescence emission and excitation spectra to mononuclear complexes 8 and 10, so obliviously there was almost no influence on position of energy levels. Therefore, no significant photophysical differences between mononuclear and binuclear complexes were observed. 


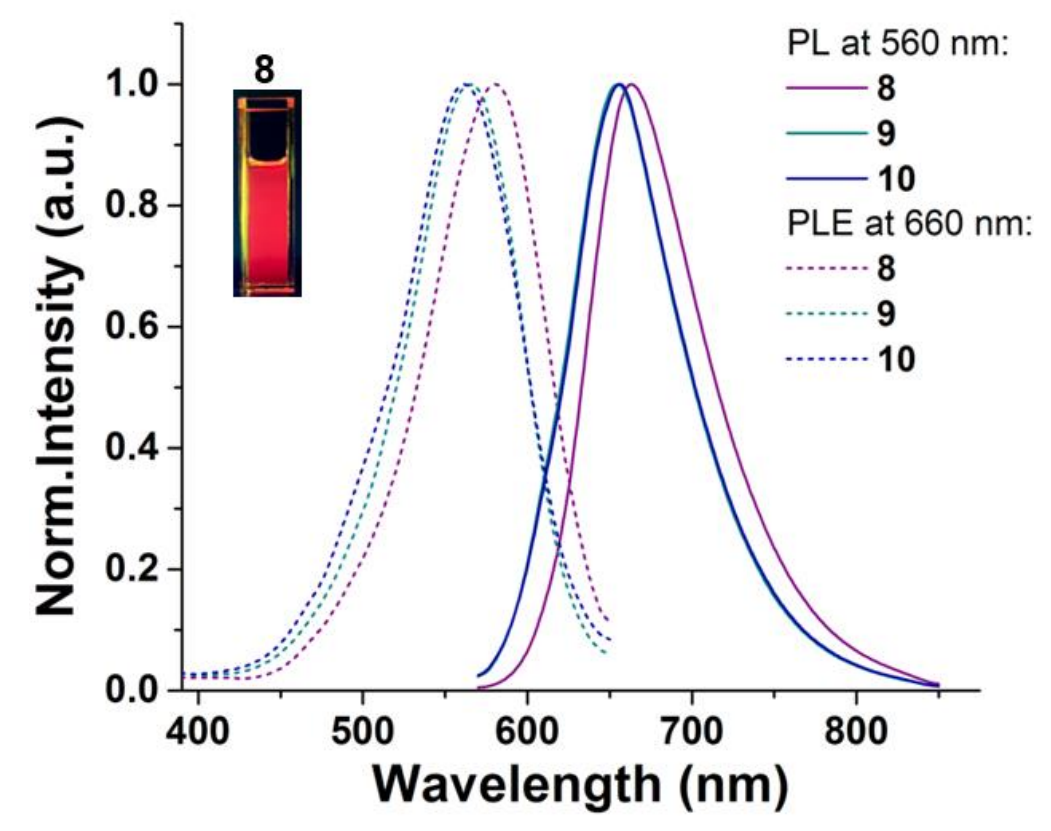

Figure 5. Normalized PL and PLE spectra of 8-10 in $\mathrm{CH}_{2} \mathrm{Cl}_{2}$.

\subsection{Cytotoxicity Evaluation}

Since photoactive transition metal complexes hold promise for the development of novel methods which would feature advantageous control of drug-action specificity [22] (see Introduction), and 5-10 emit in near-infrared region and can be excited with a visible light, what might be useful for bioimaging, we decided to evaluate their cytotoxicity to human cancer and healthy cells. The antiproliferative activity of uncoordinated ligand 3 and its $\mathrm{Zn}^{\mathrm{II}}, \mathrm{Cd}^{\mathrm{II}}$, and $\mathrm{Hg}^{\mathrm{II}}$ complexes 5-7 were evaluated against the human HCT116 colorectal carcinoma, MCF7 breast adenocarcinoma, A549 non-small cell lung carcinoma and WI38 nonmalignant lung fibroblast cell lines by means of standard MTT colorimetric assay as the $\mathrm{IC}_{50}$ value (concentration of a compound required to inhibit the cell viability by $50 \%$ ) after $72 \mathrm{~h}$ of incubation (Table 2). Overall, cytotoxicity data showed no restriction for bioimaging applications for 5-10.

Table 2. Cytotoxicity $\left(\mathrm{IC}_{50}, \mu \mathrm{M}\right)$ of 3 and 5-7 following incubation for $72 \mathrm{~h}$ with human HCT116 colorectal carcinoma, MCF7 breast adenocarcinoma, A549 non-small cell lung carcinoma and WI38 nonmalignant lung fibroblast cell lines.

\begin{tabular}{ccccc}
\hline & HCT116 & MCF7 & A549 & WI38 \\
\hline $\mathbf{3}$ & $38.8 \pm 0.4$ & $27.3 \pm 1.5$ & $33.5 \pm 5.3$ & $>100$ \\
$\mathbf{5}$ & $>100$ & $>100$ & $>100$ & $>100$ \\
$\mathbf{5}$ & $>100$ & $>100$ & $>100$ & $>100$ \\
$\mathbf{6}$ & $>100$ & $42.8 \pm 0.1$ & $17.1 \pm 3.5$ & $53.5 \pm 2.0$ \\
$\mathbf{7}$ & $10.4 \pm 2.4$ & $14.2 \pm 2.5$ & $30.0 \pm 3.3$ & $6.4 \pm 1.3$ \\
Cisplatin & $12.3 \pm 1.7$ & $12.5 \pm 1.2$ & $8.8 \pm 0.9$ & $3.0 \pm 0.7$ \\
\hline
\end{tabular}

Complex 3 showed moderate activity in the range of 38 to $27 \mu \mathrm{M}$ against cancer cell lines, and no activity on the WI38 cell line. Complexes 5-7 displayed metal-dependent activity: Zn complex 5 showed no activity, while $6\left(\mathrm{Cd}^{\mathrm{II}}\right)$ exhibited a moderate activity and $7\left(\mathrm{Hg}^{\mathrm{II}}\right)$ found to be the most cytotoxic with antiproliferative activity close to that of cisplatin on some cell lines (Table 1). 


\section{Conclusions}

In summary, we described the synthesis and characterization of group 12 metal complexes of two triarylazoimidazoles (3 and 4), which exhibit highly efficient orangered or red photoluminescence in a solution ( $\Phi$ up to 0.44 ). The emission can be excited with green light. Our studies highlight unexplored potential of triarylazoimidazoles for the development of a new class of emissive transition metal complexes. Further studies into synthesis of triarylazoimidazoles carrying various substituents and their metal complexes, photophysical properties, and applications are underway and will be reported in due course.

\section{Materials and Methods}

General remarks. Unless stated otherwise, all the reagents used in this study were obtained from the commercial sources (Aldrich, TCI-Europe, Strem, ABCR). NMR spectra were recorded on a Bruker Avance III, Karlsruhe, Germany $\left({ }^{1} \mathrm{H}: 400 \mathrm{MHz}\right)$; chemical shifts $(\delta)$ are given in ppm relative to TMS, coupling constants $(\mathrm{J})$ in Hz. The solvent signals were used as references $\left(\mathrm{CDCl}_{3}: \delta_{\mathrm{C}}=77.16 \mathrm{ppm}\right.$; residual $\mathrm{CHCl}_{3}$ in $\mathrm{CDCl}_{3}: \delta_{\mathrm{H}}=7.26 \mathrm{ppm}$; $\mathrm{CD}_{2} \mathrm{Cl}_{2}: \delta_{\mathrm{C}}=53.84 \mathrm{ppm}$; residual $\mathrm{CHDCl}_{2}$ in $\left.\mathrm{CD}_{2} \mathrm{Cl}_{2}: \delta_{\mathrm{H}}=5.32 \mathrm{ppm}\right) ;{ }^{1} \mathrm{H}$ and ${ }^{13} \mathrm{C}$ assignments were established using NOESY, HSQC, and HMBC experiments; numbering schemes as shown in the Inserts. IR: Perkin-Elmer Spectrum One spectrometer, wavenumbers $(\tilde{v})$ in $\mathrm{cm}^{-1}$. C, H, and N elemental analyses were carried out on a Euro EA 3028HT CHNS/O analyzer (Pavia, Italy). Mass-spectra were obtained on a Bruker micrOTOF spectrometer equipped with electrospray ionization (ESI) source (Bremen, Germany); $\mathrm{MeOH}, \mathrm{CH}_{2} \mathrm{Cl}_{2}$, or $\mathrm{MeOH} / \mathrm{CH}_{2} \mathrm{Cl}_{2}$ mixture was used as a solvent. Thermogravimetric analysis (TGA) and differential thermal analysis were determined using a Netzsch TG 209F1 Libra apparatus (Selb, Germany). Solvents were purified by distillation over the indicated drying agents and were transferred under Ar: $\mathrm{Et}_{2} \mathrm{O}\left(\mathrm{Mg} /\right.$ anthracene), $\mathrm{CH}_{2} \mathrm{Cl}_{2}\left(\mathrm{CaH}_{2}\right)$, hexane $(\mathrm{Na} / \mathrm{K})$. Flash chromatography: Merck Geduran ${ }^{\circledR S i} 60(40-63 \mu \mathrm{m})$. Absorption spectra were measured in a $4 \mathrm{~mL}$ quartz cuvette using a UV-VIS spectrometer (UV-3600, Shimadzu, Kyoto, Japan) and luminescence emission and excitation spectra in the same cuvette - using a spectrofluorimeter (RF-5031PC, Shimadzu, Kyoto, Japan). The luminescence quantum yield was determined using the slope method relative to the reference fluorophore, which was the ethanol solution of rhodamine $B(\Phi=0.68)$ excited at $540 \mathrm{~nm}$ for the complexes 5-7 and the ethanol solution of Nile Blue due $(\Phi=0.17)$ excited at $560 \mathrm{~nm}$ for complexes 8-10, using a series of ethanol solutions of the sample with varying concentrations. The luminescence lifetime was measured using frequency-doubled pulses of a femtosecond titanium-sapphire oscillator (Tsunami, Spectra-Physics, Santa Clara, CA, USA) with a central wavelength of $490 \mathrm{~nm}$, repetition rate of $80 \mathrm{MHz}$, duration of $100 \mathrm{fs}$, and pulse energy of $10 \mathrm{pJ}$. After passing through a FESH0750 dielectric filter (Thorlabs, Newton, NJ, USA) mounted at an angle of $45^{\circ}$, femtosecond laser pulses were coupled into an objective lens (Olympus, 20×, $0.55 \mathrm{NA}$ ) and focused into a penicillin vial with a sample. Luminescence was collected by the same lens, filtered by a long-pass filter (FELH0500, Thorlabs), and directed to a monochromator (Acton SP300i, Sarasota, FL, USA), where it was detected by the photomultiplier tube of a time-correlated photon counting system (SPC-150N, Becker and Hickl GmbH, Berlin, Germany), which recorded the luminescence decay kinetics in the time range of $0-12.5 \mathrm{~ns}$ with a resolution of $20 \mathrm{ps}$. Decay kinetics were monitored at the emission wavelength of $600 \mathrm{~nm}$ for 5-7 and $660 \mathrm{~nm}$-for 8-10. Instrumental response function (IRF) was measured at $490 \mathrm{~nm}$ using reflection of the laser beam from a coverslip surface. Parameters of mono- and multiexponential decay were found by deconvolution of the measured decay kinetics using the SPCImage 8.1 software (Becker and Hickl GmbH, Berlin, Germany) and registered IRF. Luminescence decay kinetics were fit with either a mono- or multiexponential decay function using the SPCImage software (Becker and Hickl $\mathrm{GmbH})$. Coefficients of the multiexponential fit $A_{i}$ were normalized so that $\sum_{i} A_{i}=1$. Effective decay time $T_{\text {eff }}$ was calculated as $T_{\text {eff }}=\sum_{i} A_{i} T_{i}$. 
General procedure for the synthesis of triarylazoimidazoles 3 and 4. Methanol solution of $\mathrm{NaOMe}$ (30 wt \%, 1 equivalent, for the quantity see below) and a solution of $p$-anisyldiazonium tetrafluoroborate (1 equivalent) in $10 \mathrm{~mL} \mathrm{MeCN}$ and were sequentially added to a solution of diarylimidazole 1 or 2 in $\mathrm{MeOH}(25 \mathrm{~mL})$. The resulting mixture stirred for $1 \mathrm{~h}$, evaporated, redissolved in $\mathrm{CH}_{2} \mathrm{Cl}_{2}$, filtered, evaporated again, washed with $\mathrm{Et}_{2} \mathrm{O}(3 \times 3 \mathrm{~mL})$, and dried under vacuum.

3. $p$-anisyldiazonium tetrafluoroborate $(2.270 \mathrm{mmol}, 504 \mathrm{mg}), 4,5$-bis-(phenyl)imidazole (2.270 mmol, $500 \mathrm{mg}$ ) and $\mathrm{NaOMe}(2.270 \mathrm{mmol}, 425 \mu \mathrm{L})$ were used. Yield: $748 \mathrm{mg}(93 \%)$. Elem. anal. calcd for $\mathrm{C}_{22} \mathrm{H}_{18} \mathrm{~N}_{4} \mathrm{O}$ : C 74.56; $\mathrm{H}$ 5.12; $\mathrm{N}$ 15.81. Found: $\mathrm{C} 74.89 ; \mathrm{H}$ 5.62; N 15.41. ${ }^{1} \mathrm{H}$ NMR $(400 \mathrm{MHz}, \mathrm{DMSO}-d 6): \delta 7.91(\mathrm{~d}, J=9.1 \mathrm{~Hz}, 2 \mathrm{H}), 7.31-7.47(\mathrm{~m}, 10 \mathrm{H})$, $7.16(\mathrm{~d}, J=9.1 \mathrm{~Hz}, 2 \mathrm{H}), 3.88(\mathrm{~s}, 3 \mathrm{H})$. $\mathrm{NH}$ proton was not observed due to the exchange with DMSO-d6. ${ }^{13} \mathrm{C}\left\{{ }^{1} \mathrm{H}\right\}$ NMR (151 MHz, DMSO-d6): $\delta$ 209.9, 162.2, 153.9, 146.5, 134.9, 129.0, 128.5, 124.5, 114.9, 55.7. MS (ESI $\left.{ }^{+}\right)$, found: $355.1553\left[\mathrm{M}+\mathrm{H}^{+}\right.$; calcd for $\mathrm{C}_{22} \mathrm{H}_{19} \mathrm{~N}_{4} \mathrm{O}$ : 355.1556. UV/Vis $\left(\mathrm{CH}_{2} \mathrm{Cl}_{2}\right): \lambda_{\max }=441 \mathrm{~nm}, \varepsilon=2.83 \times 10^{4} \mathrm{M}^{-1} \mathrm{~cm}^{-1}$.

4. $p$-anisyldiazonium tetrafluoroborate $(1.784 \mathrm{mmol}, 396 \mathrm{mg}), 4,5$-bis-( $p$-anisyl)imidaz- ole $(1.784 \mathrm{mmol}, 500 \mathrm{mg})$ and $\mathrm{NaOMe}(1.784 \mathrm{mmol}, 335 \mu \mathrm{L})$ were used. Yield: $658 \mathrm{mg}(89 \%)$. Elem. anal. calcd for $\mathrm{C}_{24} \mathrm{H}_{22} \mathrm{~N}_{4} \mathrm{O}_{3}$ : C 69.55; $\mathrm{H} 5.35 ; \mathrm{N} 13.52$. Found: $\mathrm{C} 69.81 ; \mathrm{H} 5.76 ; \mathrm{N} 13.18$. ${ }^{1} \mathrm{H}$ NMR (400 MHz, DMSO-d6): $\delta 7.80(\mathrm{~d}, J=9.0 \mathrm{~Hz}, 2 \mathrm{H}), 7.42(\mathrm{~d}, J=8.8 \mathrm{~Hz}, 4 \mathrm{H}), 7.07(\mathrm{~d}$, $J=9.0 \mathrm{~Hz}, 2 \mathrm{H}), 6.89(\mathrm{~d}, J=8.8 \mathrm{~Hz}, 4 \mathrm{H}), 3.82(\mathrm{~s}, 3 \mathrm{H}), 3.74(\mathrm{~s}, 6 \mathrm{H})$. NH proton was not observed due to the exchange with DMSO-d6. ${ }^{13} \mathrm{C}\left\{{ }^{1} \mathrm{H}\right\}$ NMR (151 MHz, DMSO-d6): $\delta 206.5,161.1$, 158.4, 147.1, 129.1, 123.8, 114.6, 113.7, 55.6, 55.1. MS (ESI ${ }^{+}$), found: $415.1776[\mathrm{M}+\mathrm{H}]^{+}$; calcd for $\mathrm{C}_{24} \mathrm{H}_{23} \mathrm{~N}_{4} \mathrm{O}_{3}$ : 415.1770. UV/Vis $\left(\mathrm{CH}_{2} \mathrm{Cl}_{2}\right): \lambda_{\max }=465 \mathrm{~nm}, \varepsilon=2.24 \times 10^{4} \mathrm{M}^{-1} \mathrm{~cm}^{-1}$.

General procedure for the synthesis of 5-10. Methanol solution (1 mL) of 3 or 4 (1 equivalent, for the quantity see below) was added to a solution of an appropriate metal halide ( 1 equivalent) in $1 \mathrm{~mL} \mathrm{MeOH}(1 \mathrm{~mL})$. The resulting mixture was kept without stirring for $24 \mathrm{~h}$, the formed precipitate was filtered, washed with $\mathrm{MeOH}(3 \times 1 \mathrm{~mL}), \mathrm{Et}_{2} \mathrm{O}$ $(3 \times 3 \mathrm{~mL})$, and dried under vacuum.

5. Complex 3 (0.141 mmol, $50 \mathrm{mg}), \mathrm{ZnCl}_{2}(0.141 \mathrm{mmol}, 19 \mathrm{mg})$ were used. Yield: $32 \mathrm{mg}$ (46\%). Elem. anal. calcd for $\mathrm{C}_{22} \mathrm{H}_{18} \mathrm{Cl}_{2} \mathrm{~N}_{4} \mathrm{OZn}$ : C 53.85; $\mathrm{H} 3.70 ; \mathrm{N} 11.42$. Found: $\mathrm{C}$ 54.16; $\mathrm{H} 4.04 ; \mathrm{N} 10.98 .{ }^{1} \mathrm{H}$ and ${ }^{13} \mathrm{C}\left\{{ }^{1} \mathrm{H}\right\}$ NMR spectra were not obtained due to the low solubility of the compound in the common deuterated solvents. Crystals, suitable for X-ray analysis, were obtained from the reaction mixture. UV/Vis $\left(\mathrm{CH}_{2} \mathrm{Cl}_{2}\right): \lambda_{\max }=508 \mathrm{~nm}$, $\varepsilon=3.04 \times 10^{4} \mathrm{M}^{-1} \mathrm{~cm}^{-1}$.

6. Complex 3 (0.141 mmol, $50 \mathrm{mg}), \mathrm{CdCl}_{2} 2 \mathrm{H}_{2} \mathrm{O}(0.141 \mathrm{mmol}, 26 \mathrm{mg})$ were used. Yield: $40 \mathrm{mg}(53 \%)$. Elem. anal. calcd for $\mathrm{C}_{44} \mathrm{H}_{36} \mathrm{Cd}_{2} \mathrm{Cl}_{4} \mathrm{~N}_{8} \mathrm{O}_{2}$ : C 49.14; $\mathrm{H} 3.37 ; \mathrm{N}$ 10.42. Found: C 49.56; H 3.74; $\mathrm{N} 10.11 .{ }^{1} \mathrm{H}$ and ${ }^{13} \mathrm{C}\left\{{ }^{1} \mathrm{H}\right\}$ NMR spectra were not obtained due to the low solubility of the compound in the common deuterated solvents. Crystals, suitable for $\mathrm{X}$-ray analysis, were obtained from the reaction mixture. UV/Vis $\left(\mathrm{CH}_{2} \mathrm{Cl}_{2}\right): \lambda_{\max }=441 \mathrm{~nm}$, $\varepsilon=2.65 \times 10^{4} \mathrm{M}^{-1} \mathrm{~cm}^{-1}$.

7. Complex 3 (0.141 mmol, $50 \mathrm{mg}), \mathrm{HgCl}_{2}(0.141 \mathrm{mmol}, 38 \mathrm{mg})$ were used. Yield: $60 \mathrm{mg}$ (68\%). Elem. anal. calcd for $\mathrm{C}_{22} \mathrm{H}_{18} \mathrm{Cl}_{2} \mathrm{HgN}_{4} \mathrm{O}$ : C 42.22; $\mathrm{H}$ 2.90; $\mathrm{N}$ 8.95. Found: $\mathrm{C}$ 42.64; $\mathrm{H} 3.28 ; \mathrm{N}$ 8.68. ${ }^{1} \mathrm{H}$ and ${ }^{13} \mathrm{C}\left\{{ }^{1} \mathrm{H}\right\}$ NMR spectra were not obtained due to the low solubility of the compound in the common deuterated solvents. Crystals, suitable for $\mathrm{X}$-ray analysis, were obtained from the reaction mixture. UV/Vis $\left(\mathrm{CH}_{2} \mathrm{Cl}_{2}\right): \lambda_{\max }=442 \mathrm{~nm}$, $\varepsilon=2.81 \times 10^{4} \mathrm{M}^{-1} \mathrm{~cm}^{-1}$.

8. Complex $4(0.121 \mathrm{mmol}, 50 \mathrm{mg}), \mathrm{ZnCl}_{2}(0.121 \mathrm{mmol}, 16.5 \mathrm{mg})$ were used. Yield: $38 \mathrm{mg}(57 \%)$. Elem. anal. calcd for $\mathrm{C}_{24} \mathrm{H}_{22} \mathrm{Cl}_{2} \mathrm{ZnN}_{4} \mathrm{O}_{3}$ : C 52.34; $\mathrm{H} 4.03 ; \mathrm{N}$ 10.17. Found: C 52.56; $\mathrm{H} 4.43 ; \mathrm{N} 9.78 .{ }^{1} \mathrm{H}$ and ${ }^{13} \mathrm{C}\left\{{ }^{1} \mathrm{H}\right\}$ NMR spectra were not obtained due to the low solubility of the compound in the common deuterated solvents. Crystals, suitable for X-ray analysis, were obtained from the reaction mixture. UV/Vis $\left(\mathrm{CH}_{2} \mathrm{Cl}_{2}\right): \lambda_{\max }=542 \mathrm{~nm}$, $\varepsilon=2.72 \times 10^{4} \mathrm{M}^{-1} \mathrm{~cm}^{-1}$. 
9. Complex 4 (0.121 mmol, $50 \mathrm{mg}), \mathrm{CdCl}_{2} 2 \mathrm{H}_{2} \mathrm{O}(0.121 \mathrm{mmol}, 22 \mathrm{mg})$ were used. Yield: $31 \mathrm{mg}$ (43\%). Elem. anal. calcd for $\mathrm{C}_{48} \mathrm{H}_{44} \mathrm{Cd}_{2} \mathrm{Cl}_{4} \mathrm{~N}_{8} \mathrm{O}_{6}: \mathrm{C} 48.22 ; \mathrm{H} 3.71 ; \mathrm{N}$ 9.37. Found: C 48.58; H 3.35; N 8.89. ${ }^{1} \mathrm{H}$ and ${ }^{13} \mathrm{C}\left\{{ }^{1} \mathrm{H}\right\}$ NMR spectra were not obtained due to the low solubility of the compound in the common deuterated solvents. Crystals, suitable for X-ray analysis, were obtained from the reaction mixture. UV/Vis $\left(\mathrm{CH}_{2} \mathrm{Cl}_{2}\right): \lambda_{\max }=479 \mathrm{~nm}$, $\varepsilon=1.90 \times 10^{4} \mathrm{M}^{-1} \mathrm{~cm}^{-1}$.

10. Complex 4 ( $0.121 \mathrm{mmol}, 50 \mathrm{mg}), \mathrm{HgCl}_{2}(0.121 \mathrm{mmol}, 33 \mathrm{mg})$ were used. Yield: $59 \mathrm{mg}$ (71\%). Elem. anal. calcd for $\mathrm{C}_{24} \mathrm{H}_{22} \mathrm{Cl}_{2} \mathrm{HgN}_{4} \mathrm{O}_{3}$ : C 42.02; $\mathrm{H}$ 3.23; $\mathrm{N}$ 8.17. Found: $\mathrm{C}$ 42.28; $\mathrm{H}$ 3.13; N 7.73. ${ }^{1} \mathrm{H}$ and ${ }^{13} \mathrm{C}\left\{{ }^{1} \mathrm{H}\right\}$ NMR spectra were not obtained due to the low solubility of the compound in the common deuterated solvents. Crystals, suitable for X-ray analysis, were obtained from the reaction mixture. UV/Vis $\left(\mathrm{CH}_{2} \mathrm{Cl}_{2}\right): \lambda_{\max }=474 \mathrm{~nm}$, $\varepsilon=2.06 \times 10^{4} \mathrm{M}^{-1} \mathrm{~cm}^{-1}$.

X-ray diffraction studies. Single crystals of $5 \cdot \mathrm{CH}_{3} \mathrm{OH}, 7 \cdot \mathrm{CH}_{3} \mathrm{OH}, 8 \cdot \mathrm{CH}_{3} \mathrm{OH}, 9 \cdot 2 \mathrm{CH}_{3} \mathrm{OH}$, and $10 \cdot \mathrm{CH}_{3} \mathrm{OH}$ were obtained from reaction mixtures. XRD data were collected using equipment of the Center for Molecular Studies of INEOS RAS. Intensities of the reflections for these crystals were collected with Bruker Apex II Duo CCD diffractometer (for 5. $\mathrm{CH}_{3} \mathrm{OH}, 7 \cdot \mathrm{CH}_{3} \mathrm{OH}, 8 \cdot \mathrm{CH}_{3} \mathrm{OH}$, and $10 \cdot \mathrm{CH}_{3} \mathrm{OH}$ ) at $120.0(2) \mathrm{K}$ and with Bruker Quest diffractometer with $\mathrm{PHOTON}$ detector (for $9 \cdot 2 \mathrm{CH}_{3} \mathrm{OH}$ ) at room temperature (MoK $\alpha$ radiation, $\lambda=0.71073 \AA$ ). The structures were solved by the SHELXT method [32] and refined by full-matrix least squares against $F^{2}$. Non-hydrogen atoms were refined anisotropically except for a disordered methoxyphenyl fragment of $9 \cdot 2 \mathrm{CH}_{3} \mathrm{OH}$. The methoxyphenyl is equally disordered over two sites, and non-hydrogen atoms for this fragment were refined isotropically $\mathrm{H}(\mathrm{N})$ and $\mathrm{H}(\mathrm{O})$ atoms were located on difference Fourier maps, and those of $\mathrm{H}(\mathrm{C})$ atoms were calculated. All hydrogen atoms were included in a refinement by the riding model with $U_{i s o}(\mathrm{H})=1.5 U_{e q}(\mathrm{X})$ for methyl and hydroxy groups and $1.2 U_{e q}(X)$ for the other atoms. All calculations were made using the SHELXL2014 [33] and OLEX2 [34] program packages. Crystallographic parameters and refinement details for all complexes are listed in Table S1. Overall, metrical parameters for triarylazoimidazoles in 5, 7-10 are similar to those reported for structurally relevant azocompounds [17-19,23,35,36] and imidazole derivatives [37,38]. CCDC 2058877-2058881 contain the supplementary crystallographic data for this paper. These data can be obtained free of charge via http:/ / www.ccdc.cam.ac.uk/structures / (accessed 17 March 2021).

Supplementary Materials: The following are available online. Table S1. Crystallographic data and the refinement parameters for the crystals of 5, 7-10. Figure S1. H-bonded architectures in 5, 7 and 9. Figure S2. UV-VIS spectra of $\mathbf{4}$ and its group 12 metal complexes 8-10 in $\mathrm{CH}_{2} \mathrm{Cl}_{2}$. Figure S3. UV-VIS spectrum of $\mathbf{5}$ and its second derivative. Figure S4. PLE spectrum of $\mathbf{5}$ and its second derivative. Figure S5. UV-VIS spectrum of 8 and its second derivative. Figure S6. PLE spectrum of 8 and its second derivative. Table S2. Photophysical properties of ligands $\mathbf{3}$ and $\mathbf{4}$ and their complexes 5-10 in $\mathrm{CH}_{2} \mathrm{Cl}_{2}$. Table S3. Parameters of multiexponential fit of photoluminescence decay kinetics of complexes 5-7 and 8-10 in $\mathrm{CH}_{2} \mathrm{Cl}_{2}$. Figure S7. PL and PLE spectra of $\mathbf{5}$ in ethanol, acetonitrile, dichloromethane and toluene.

Author Contributions: Conceptualization, A.G.T.; writing-review and editing; writing-original draft preparation, A.G.T.; V.G.N. and A.G.T.; investigation, A.A.A., O.V.R., B.S.T., A.A.N., M.R.G., A.V.V., V.N.K., A.S.K., supervision, V.N.N. All authors have read and agreed to the published version of the manuscript.

Funding: This work was performed under the support of the Russian Science Foundation (award no. 20-73-00094).

Institutional Review Board Statement: Not applicable.

Informed Consent Statement: Not applicable.

Acknowledgments: XRD data were collected using equipment of the Center for Molecular Studies of INEOS RAS. 
Conflicts of Interest: The authors declare no conflict of interest.

Sample Availability: Samples of the compounds 3-10 are available from the authors.

\section{References}

1. Xu, H.; Chen, R.; Sun, Q.; Lai, W.; Su, Q.; Huang, W.; Liu, X. Recent progress in metal-organic complexes for optoelectronic applications. Chem. Soc. Rev. 2014, 43, 3259-3302. [CrossRef] [PubMed]

2. Yersin, H.; Rausch, A.F.; Czerwieniec, R.; Hofbeck, T.; Fischer, T. The triplet state of organo-transition metal compounds. Triplet harvesting and singlet harvesting for efficient OLEDs. Coord. Chem. Rev. 2011, 255, 2622-2652. [CrossRef]

3. Zhou, G.; Wong, W.-Y.; Poon, S.-Y.; Ye, C.; Lin, Z. Symmetric Versus Unsymmetric Platinum(II) Bis(aryleneethynylene)s with Distinct Electronic Structures for Optical Power Limiting/Optical Transparency Trade-off Optimization. Adv. Funct. Mater. 2009, 19, 531-544. [CrossRef]

4. Dai, F.-R.; Zhan, H.-M.; Liu, Q.; Fu, Y.-Y.; Li, J.-H.; Wang, Q.-W.; Xie, Z.; Wang, L.; Yan, F.; Wong, W.-Y. Platinum(II)Bis(aryleneethynylene) Complexes for Solution-Processible Molecular Bulk Heterojunction Solar Cells. Chem. A Eur. J. 2012, 18, 1502-1511. [CrossRef] [PubMed]

5. Zhao, Q.; Li, F.; Huang, C. Phosphorescent chemosensors based on heavy-metal complexes. Chem. Soc. Rev. 2010, 39, 3007-3030. [CrossRef]

6. Liu, Z.; He, W.; Guo, Z. Metal coordination in photoluminescent sensing. Chem. Soc. Rev. 2013, 42, 1568-1600. [CrossRef] [PubMed]

7. Loudet, A.; Burgess, K. BODIPY dyes and their derivatives: Syntheses and spectroscopic properties. Chem. Rev. 2007, 107, 4891-4932. [CrossRef]

8. Monro, S.; Colón, K.L.; Yin, H.; Roque, J.; Konda, P.; Gujar, S.; Thummel, R.P.; Lilge, L.; Cameron, C.G.; McFarland, S.A. Transition Metal Complexes and Photodynamic Therapy from a Tumor-Centered Approach: Challenges, Opportunities, and Highlights from the Development of TLD1433. Chem. Rev. 2019, 119, 797-828. [CrossRef]

9. Prier, C.K.; Rankic, D.A.; MacMillan, D.W.C. Visible Light Photoredox Catalysis with Transition Metal Complexes: Applications in Organic Synthesis. Chem. Rev. 2013, 113, 5322-5363. [CrossRef]

10. Xuan, J.; Xiao, W.-J. Visible-Light Photoredox Catalysis. Angew. Chemie Int. Ed. 2012, 51, 6828-6838. [CrossRef]

11. Zhang, Y.; Lee, T.S.; Favale, J.M.; Leary, D.C.; Petersen, J.L.; Scholes, G.D.; Castellano, F.N.; Milsmann, C. Delayed fluorescence from a zirconium(iv) photosensitizer with ligand-to-metal charge-transfer excited states. Nat. Chem. 2020, 12, 345-352. [CrossRef]

12. Sarker, K.K.; Chand, B.G.; Suwa, K.; Cheng, J.; Lu, T.H.; Otsuki, J.; Sinha, C. Structural studies and photochromism of mercury(II)iodo complexes of (arylazo)imidazoles. Inorg. Chem. 2007, 46, 670-680. [CrossRef]

13. Sarker, K.K.; Sardar, D.; Suwa, K.; Otsuki, J.; Sinha, C. Cadmium(II) complexes of (Arylazo)imidazoles: Synthesis, structure, photochromism, and density functional theory calculation. Inorg. Chem. 2007, 46, 8291-8301. [CrossRef] [PubMed]

14. Schütt, C.; Heitmann, G.; Wendler, T.; Krahwinkel, B.; Herges, R. Design and synthesis of photodissociable ligands based on azoimidazoles for light-driven coordination-induced spin state switching in homogeneous solution. J. Org. Chem. 2016, 81, 1206-1215. [CrossRef]

15. Das, D.; Nayak, M.K.; Sinha, C. Chemistry of azoimidazoles. Synthesis, spectral characterization and redox studies of N(1)benzyl-2-(arylazo)imidazolepalladium(II)chloride. Transit. Met. Chem. 1997, 22, 172-175. [CrossRef]

16. Misra, T.K.; Das, D.; Sinha, C. Chemistry of azoimidazoles: Synthesis, spectral characterization and redox properties of bis(N(1)alkyl-2-(arylazo)imidazole) copper(I) and silver(I) complexes. Polyhedron 1997, 16, 4163-4170. [CrossRef]

17. Tskhovrebov, A.G.; Naested, L.C.E.; Solari, E.; Scopelliti, R.; Severin, K. Synthesis of azoimidazolium dyes with nitrous oxide. Angew. Chem. Int. Ed. 2015, 54, 1289-1292. [CrossRef]

18. Eymann, L.Y.M.; Tskhovrebov, A.G.; Sienkiewicz, A.; Bila, J.L.; Živković, I.; Rønnow, H.M.; Wodrich, M.D.; Vannay, L.; Corminboeuf, C.; Pattison, P.; et al. Neutral Aminyl Radicals Derived from Azoimidazolium Dyes. J. Am. Chem. Soc. 2016, 138, 15126-15129. [CrossRef]

19. Liu, Y.; Varava, P.; Fabrizio, A.; Eymann, L.Y.M.; Tskhovrebov, A.G.; Planes, O.M.; Solari, E.; Fadaei-Tirani, F.; Scopelliti, R.; Sienkiewicz, A.; et al. Synthesis of aminyl biradicals by base-induced Csp3-Csp3 coupling of cationic azo dyes. Chem. Sci. 2019, 10, 5719-5724. [CrossRef]

20. Otsuki, J.; Suwa, K.; Sarker, K.K.; Sinha, C. Photoisomerization and thermal isomerization of arylazoimidazoles. J. Phys. Chem. A 2007, 111, 1403-1409. [CrossRef]

21. Crespi, S.; Simeth, N.A.; König, B. Heteroaryl azo dyes as molecular photoswitches. Nat. Rev. Chem. 2019, 3, 133-146. [CrossRef]

22. Presa, A.; Brissos, R.F.; Caballero, A.B.; Borilovic, I.; Korrodi-Gregório, L.; Pérez-Tomás, R.; Roubeau, O.; Gamez, P. Photoswitching the Cytotoxic Properties of Platinum(II) Compounds. Angew. Chem. Int. Ed. 2015, 54, 4561-4565. [CrossRef] [PubMed]

23. Tskhovrebov, A.G.; Vasileva, A.A.; Goddard, R.; Riedel, T.; Dyson, P.J.; Mikhaylov, V.N.; Serebryanskaya, T.V.; Sorokoumov, V.N.; Haukka, M. Palladium(II)-Stabilized Pyridine-2-Diazotates: Synthesis, Structural Characterization, and Cytotoxicity Studies. Inorg. Chem. 2018, 57, 930-934. [CrossRef]

24. Hammam, A.M.; Rageh, N.M.; Ibrahim, S.A. Solvatochromic studies on 2-[(2-hydroxypheny)azo]-4-5-diphenylimidazole. Dye Pigment. 1997, 35, 289-296. [CrossRef]

25. Mahmoud, M.R.; Hammam, A.M.; El-Gyar, S.A.; Ibrahim, S.A. Coordination compounds of heterocyclic azo derivatives. III. $\mathrm{Co}(\mathrm{II}), \mathrm{Ni}(\mathrm{II})$ and $\mathrm{Cu}(\mathrm{II})$ complexes of some arylazo-4,5-diphenylimidazole derivatives. Mon. Chem. Chem. Mon. 1986, 117, 313-325. [CrossRef] 
26. Teranishi, H.; Takagawa, K.; Arai, Y.; Wakaki, K.; Sumi, Y.; Takaya, K. Histological Staining of Cadmium with 2-(8-quinolylazo)4,5-diphenylimidazole (QAI) in the Kidneys of Rats Periorally Exposed to Cadmium. J. Occup. Health 2002, 44, 60-62. [CrossRef]

27. Shabaa, G.J. Cloud point extraction for separation, preconcentration and determination zinc (Ii) in different pharmaceutical samples. Int. J. Res. Pharm. Sci. 2019, 10, 3006-3012. [CrossRef]

28. Tskhovrebov, A.G.; Novikov, A.S.; Odintsova, O.V.; Mikhaylov, V.N.; Sorokoumov, V.N.; Serebryanskaya, T.V.; Starova, G.L. Supramolecular polymers derived from the PtII and PdII schiff base complexes via C(sp2)-H ... Hal hydrogen bonding: Combined experimental and theoretical study. J. Organomet. Chem. 2019, 886, 71-75. [CrossRef]

29. Repina, O.V.; Novikov, A.S.; Khoroshilova, O.V.; Kritchenkov, A.S.; Vasin, A.A.; Tskhovrebov, A.G. Lasagna-like supramolecular polymers derived from the PdII osazone complexes via C(sp2)-H ․ Hal hydrogen bonding. Inorganica Chim. Acta 2020, 502, 119378. [CrossRef]

30. Mikhaylov, V.N.; Sorokoumov, V.N.; Novikov, A.S.; Melnik, M.V.; Tskhovrebov, A.G.; Balova, I.A. Intramolecular hydrogen bonding stabilizes trans-configuration in a mixed carbene/isocyanide PdII complexes. J. Organomet. Chem. 2020, 912, 121174. [CrossRef]

31. Mikhaylov, V.N.; Sorokoumov, V.N.; Liakhov, D.M.; Tskhovrebov, A.G.; Balova, I.A. Polystyrene-supported acyclic diaminocarbene palladium complexes in Sonogashira cross-coupling: Stability vs. catalytic activity. Catalysts 2018, 8, 141. [CrossRef]

32. Sheldrick, G.M. SHELXT - Integrated space-group and crystal-structure determination. Acta Crystallogr. Sect. A Found. Crystallogr. 2015, 71, 3-8. [CrossRef] [PubMed]

33. Sheldrick, G.M. Crystal structure refinement with SHELXL. Acta Crystallogr. Sect. C Struct. Chem. 2015, 71, 3-8. [CrossRef] [PubMed]

34. Dolomanov, O.V.; Bourhis, L.J.; Gildea, R.J.; Howard, J.A.K.; Puschmann, H. OLEX2: A complete structure solution, refinement and analysis program. J. Appl. Crystallogr. 2009, 42, 339-341. [CrossRef]

35. Tskhovrebov, A.G.; Solari, E.; Scopelliti, R.; Severin, K. Reactions of grignard reagents with nitrous oxide. Organometallics 2014, 33, 2405-2408. [CrossRef]

36. Nenajdenko, V.G.; Shikhaliyev, N.G.; Maharramov, A.M.; Bagirova, K.N.; Suleymanova, G.T.; Novikov, A.S.; Khrustalev, V.N.; Tskhovrebov, A.G. Halogenated Diazabutadiene Dyes: Synthesis, Structures, Supramolecular Features, and Theoretical Studies. Molecules 2020, 25, 5013. [CrossRef] [PubMed]

37. Tskhovrebov, A.G.; Lingnau, J.B.; Fürstner, A. Gold Difluorocarbenoid Complexes: Spectroscopic and Chemical Profiling. Angew. Chem. Int. Ed. 2019, 58, 8834-8838. [CrossRef]

38. Tskhovrebov, A.G.; Goddard, R.; Fürstner, A. Two Amphoteric Silver Carbene Clusters. Angew. Chem. Int. Ed. 2018, 57, 8089-8094. [CrossRef] 